Фармакологічні дослідження біологічно активних речовин Pharmacological researches of biologically active substances

Рекомендована д. мед. наук, проф. С. І. Климнюком

УДК 615.453.6:615.322:615.281.8

\title{
ВИВЧЕННЯ ПРОТИГЕРПЕТИЧНОЇ АКТИВНОСТІ ТАБЛЕТОК АЛЬТАБОР
}

\author{
(ㄱ. В. Крутських ${ }^{1}$, Н. В. Нестерова², С. Д. Загородня² \\ ${ }^{1}$ Національний фрармацевтичний університет, Харків \\ ${ }^{2}$ Інститут мікробіології та вірусології імені Д. К. Заболотного НАН України, Київ
}

Резюме: вивчено противірусну активність таблеток Альтабор. Визначено, що препарат володіє протигерпетичною активністю як в лікувальних, так і в профрілактичних схемах застосування.

Ключові слова: альтабор, протигерпетична активність, герпес, таблетки.

Вступ. Загальноприйнята класифікація гострих та рецидивуючих герпесвірусних захворювань людини на сьогодні все ще не прийнята. Це пов'язано $з$ тим, що поки що хворі з даними захворюваннями звертаються не до одного спеціаліста, а до лікарів різних спеціальностей - залежно від локалізації гострих та рецидивуючих процесів, внаслідок чого в клінічній практиці діагноз герпесвірусного захворювання має «топічний» характер, етіологія захворювання ігнорується і програмне етіопатогенетичне лікування не проводиться. Сьогодні герпетична інфекція привертає все більше уваги як медичного, так і немедичного кола суспільства. Це пов'язано з тим, що герпес, відомий 3 давніх часів як малорозповсюджене та малозначуще захворювання, останнім часом значно розширив своє значення в патології людини. Підвищена зацікавленість до герпетичної інфекції зумовлена також низкою інших причин і насамперед тим, що зараз вона розповсюджена в різних районах світу, уражуючи до 95 \% населення, а вірус, який її викликає, здатен уражати практично всі органи і системи людського організму і спричиняти різні фрорми інфекції - гостру, латентну і хронічну рецидивуючу $[1,2]$. Клінічно герпес перебігає як різноманітне, складне і нерідко тяжке захворювання 3 ураженням багатьох органів та тканин, що є підставою розглядати його як загальну системну хворобу організму [3, 4].

Сучасна медицина не має методів лікування, які дозволяють елімінувати вірус простого герпесу з організму людини. До недавна лікування герпесу було взагалі симптоматичним. Призначали засоби, які підсушували, знеболювали, охолоджували та запобігали інфрікуванню уражень іншими мікроорганізмами. Намагалися застосовувати і противірусні препарати (мазь з оксоліном, теброфеном), однак ефективність більшості противірусних засобів залишала бажати кращого. I сьогодні лікування герпетичної інфрекції складне і характеризується невисокою ефективністю. Тому методи лікування спрямовані на перешкоджання розвитку або відновленню тих порушень, які викликає активація вірусу герпесу в організмі. В цей час існує два основних напрямки в лікуванні герпесу, це, по-перше, застосування етіопатогенетичної противірусної терапії, основне місце в котрій відводиться ациклічним нуклеозидам - ацикловіру (зовіракс, ацикловір-акрі), валацикловіру (валтрекс) та фрамцикловіру (фамвір), та, по-друге, комплексний метод лікування, який містить імунотерапію (специсічну та неспецифічну) в поєднанні з противірусною терапією $[5,6,7,8]$.

Кількість лікарських препаратів для лікування герпетичних уражень досить обмежена, тому створення нових оригінальних препаратів є доцільним та своєчасним. Одним 3 таких лікарських засобів $€$ оригінальний вітчизняний препарат - таблетки Альтабор, створені на основі субстанції Альтабор, що володіє протигерпетичною та інтерфероногенною дією [9].

Метою нашої роботи стали дослідження з визначення протигерпетичної активності таблеток Альтабор.

Методи дослідження. Протигерпетичну активність таблеток Альтабор вивчали на моделях in vitro тa in vivo.

Для вивчення антигерпетичної активності таблеток альтабор in vitro використовували культуру клітин RK-13 (перещеплювані культури клітин нирки кроля), що перевивається, інсріковану вірусом герпесу 1-го типу, штаму VC (ВПГ) з інфекційним титром 4 - 6,5 $\lg$ ТЦД 50 або вірусним навантаженням 382248 г/екв. Культуру клітин вирощували на ростовому середовищі, що складалось 390 \% середовища RPMI 1640 (Sigma, США), 10 \% сироватки ембріону великої рогатої худоби (Sigma, США) і антибіотиків - пеніциліну та стрептоміцину ( по 100 мкг/мл).

У роботі використано таблетки. Діюча речовина: альтабор (у перерахунку на танінову кислоту і суху речовину) - 20 мг. Таблетки подрібнювали, наважку розчиняли в культуральному середовищі RPMI 1640 без сироватки до концентрації 1 мг/мл діючої речовини та стерилізували, використовуючи стерилізуючий фрільтр з діаметром пор 0,22 мкм (Sarstedt, США).

Протигерпетичну активність таблеток Альтабор вивчали в добових культурах клітин RK-13. Серед-

ISSN 2312-0967. Фармацевтичний часопис. 2015. № 2 
Фармакологічні дослідження біологічно активних речовин

Pharmacological researches of biologically active substances

овище росту зливали, на моношар клітин наносили препарат або вірус герпесу залежно від модисрікації експерименту. Через 1 год контакту неадсорбований вірус герпесу видаляли і до лунок вносили підтримуюче середовище (ростове середовище без сироватки) - профілактична схема. При лікувальній схемі наступного дня до лунок плашок, які інкубували з різними розведеннями препарату, вносили вірус герпесу в дозі 100 ТЦД $_{50}$, а до лунок, які були інфіковані вірусом герпесу, вносили препарат в діапазоні концентрацій 1,5 - 100 мкг/мл. Клітини протягом 5 діб інкубували в термостаті при $37^{\circ} \mathrm{C}$ д додаванням $\mathrm{CO}_{2}$. Через 5 діб збирали культуральне середовище з лунок плашок і визначали інфекційний титр у кожній пробі при профрілактичній та лікувальній дії препарату.

Антигерпетичну активність таблеток Альтабор in vivo вивчали відносно вірусу простого герпесу 1 на моделі герпесвірусного менінгоенцефаліту в білих безпородних мишей [10]. Препарат вводили по 0,3 мл per os за такими схемами: I - профілактична: за 24 год до інфрікування і потім щоденно протягом 3 діб; II - лікувальна: через 24 год після зараження вірусом герпесу і потім протягом 3 діб. Як референтний препарат застосовували «Віролекс» KRKA (Словенія), який найчастіше застосовують для лікування герпетичних захворювань.
Для дослідження було використано три групи тварин:

1 - миші, яким вводили альтабор в концентрації 0,5мг/кг + вірус герпесу

2 - миші, яким вводили віролекс в дозі 100 мг/кг + вірус герпесу;

3 - миші, яким вводили фрізіологічний розчин + вірус герпесу.

Результати й обговорення. Результати репродукції вірусу простого герпесу in vitro при профрілактичному та лікувальному введенні таблеток альтабор наведено в таблиці 1.

Аналізуючи отримані результати, слід зазначити, що як при лікувальній, так і при профілактичній різних концентрацій таблеток Альтабор (від 100 до 6,2 мкг/мл) спостерігалась виражена протигерпетична активність. При профрілактичній дії таблеток Альтабор мінімально активна концентрація склала 6,2 мкг/мл, для лікувальної дії - 3,1 мкг/мл.

Результати проведених досліджень in vivo представлено в таблиці 2.

На підставі отриманих даних можна зробити висновок, що таблетки Альтабор мають виражену профрілактичну дію в дозі 0,5 мг/кг per os, більш ефективно захищають мишей від герпетичного менінгоенцефраліту, ніж препарат Віролекс. Також на підставі

Таблиця 1. Вплив таблеток Альтабор на репродукцію вірусу простого герпесу

\begin{tabular}{|c|c|c|c|c|}
\hline \multirow[b]{2}{*}{$\begin{array}{c}\text { Концентрація } \\
\text { препарату, } \\
\text { мкг/мл }\end{array}$} & \multicolumn{2}{|c|}{ Профрілактична дія } & \multicolumn{2}{|c|}{ Лікувальна дія } \\
\hline & $\begin{array}{l}\text { інфекц. } \\
\text { титр, } \\
\lg \text { ТЦД }\end{array}$ & $\begin{array}{c}\text { інгібіюв. } \\
\text { індекц. } \\
\text { титру, } \\
\lg \text { ТЦД } \\
\end{array}$ & $\begin{array}{l}\text { інфрекц. } \\
\text { титр, } \\
\lg \text { ТЦД }\end{array}$ & $\begin{array}{l}\text { інгібіюв. } \\
\text { інсрекц. } \\
\text { титру, } \\
\lg \text { ТЦД } \\
\end{array}$ \\
\hline 100 & 1,0 & 3,0 & 2,0 & 2,0 \\
\hline 50 & 1,0 & 3,0 & 2,0 & 2,0 \\
\hline 25 & 0 & 4,0 & 0 & 4,0 \\
\hline 12,5 & 0 & 4,0 & 0 & 4,0 \\
\hline 6,2 & 1,0 & 3,0 & 0 & 4,0 \\
\hline 3,1 & 4,0 & 0 & 0 & 4,0 \\
\hline 1,5 & 4,0 & 0 & 4,0 & 0 \\
\hline 0 & 4,0 & - & 4,0 & - \\
\hline
\end{tabular}

Таблиця 2. Активність таблеток Альтабор при профрілактичній та лікувальній схемах дослідження

\begin{tabular}{|l|c|c|c|}
\hline \multicolumn{1}{|c|}{ Препарат } & Кількість загиблих мишей, \% & Кратність захисту & Індекс есрективності \\
\hline \multicolumn{5}{|c|}{ Профрілактична схема дослідження } \\
\hline альтабор & 33,5 & 3,0 & 66,5 \\
\hline віролекс & 70,0 & 1.4 & 28,0 \\
\hline плацебо & 100,0 & - & 60,0 \\
\hline \multicolumn{5}{|c|}{ Лікувальна схема дослідження } \\
\hline альтабор & 40,0 & 2,5 & 41,1 \\
\hline віролекс & 58,3 & 1,7 & - \\
\hline плацебо & 100 & - & \\
\hline
\end{tabular}

ISSN 2312-0967. Pharmaceutical review. 2015. № 2 
Фармакологічні дослідження біологічно активних речовин Pharmacological researches of biologically active substances

визначеного індексу ефрективності (IE=60) можна стверджувати про виражену лікувальну активність таблеток Альтабор, які значно ефективніші за Віролекс.

Висновки. Результатами проведених досліджень 3 вивчення противірусної активності таблеток Альтабор встановлено, що препарат проявляє виражену протигерпетичну активність як в лікувальній, так і профрілактичній схемах застосування. При просрілактичній дії таблеток альтабор мінімально активна концентрація склала 6,2 мкг/мл, при лікувальній дії - 3,1 мкг/мл. У дозі 0,5 мг/кг per os альтабор більш есрективно захищає мишей від герпетичного менінгоенцесраліту, ніж препарат Віролекс, в 2 рази краще при профрілактичній та в 1,5 раза при лікувальній схемах застосування.

\title{
Література
}

1. Овчинникова Л. К. Герпетическая инфекция / Л. К. Овчинникова // Фарм-спектр. - 2008. - № 20. C. $34-38$

2. Исаков В. А. Герпесвирусные инсекции человека: руководство для врачей / В. А. Исаков, Е. И. Архипова. - СПб. : СпецЛит., 2006. - 303 с.

3. Хахалин Л. Н. Герпесвирусные заболевания человека [Электронный ресурс] / Л. Н. Хахалин, Е.В.Соловьева. - Режим доступа: http://www.clinpharma com/magazine/journal5/gerp1.htm.

4. Бобрицька Л. О. Особливості перебігу та аспекти формакотерапії герпесвірусної інфекції / Л. О. Бобрицька, О. А. Рубан, Д. С. Пуляєв // Zbiór raportów naukowych. «Postępy w nauce w ostatnich latach. Nowych rozwiązań». (28.12.2012 - 30.12.2012) - Warszawa: Wydawca: Sp. z o.o. «Diamond trading tour», 2012. - Część 9. - C. 29-31.

5. Абрамова Т. В. Новые возможности терапии генитального герпеса / Т. В. Абрамова, И. Б. Мерцалова //Terra Medica. - 2012. - № 1. - C. 26 - 33.

6. Волянський Ю. Л. Дослідження специсрічної активності лікарського препарату на основі

валацикловіру / Ю. Л. Волянський, Л. О. Бобрицька // Запорожский медицинский журнал. - 2011. - Т. 13, № 6. - C. 103-105.

7. Савичук Н. О. Превентивна та протирецидивна терапія захворювань слизової оболонки порожнини рота й губ, асоційованих з вірусами герпесу / Н. О. Савичук // Современная стоматология. - 2011. - № 5. - С. 35-38.

8. Киселев О. И. Герпесвирусные инфекции: лекарственные препараты и ПЦР-мониторинг терапии [Электронный ресурс] / О. И. Киселев, Г. Р. Виноградская, М. А. Струкова. - Режим доступа: http://www.influenza. spb.ru/Herpes/book/herpes.htm.

9. Пат. на винахід 99317 Україна, МПК А61К 36/18, А61K 9/20, А61P 31/12, Фармацевтична композиція у фрормі таблеток для лікування вірусних захворювань / Тищенко Р. О., Кобилинська В. І., Крутских Т. В., Безпалько Л. В., Сова Є. О., Шаламай А. С.; - № а201007829; заявл. 22.06.2010; опубл. 10.08.2012, Бюл. № 15.

10. Доклінічні дослідження лікарських засобів : метод. реком. / за ред. чл.-кор. АМН України О. В. Стефранова К. : Авіцена, 2001. - 528 с.

\section{ИЗУЧЕНИЕ ПРОТИВОГЕРПЕТИЧЕСКОЙ АКТИВНОСТИ ТАБЛЕТОК АЛЬТАБОР}

\author{
Т. В. Крутских ${ }^{1}$, Н. В. Нестерова 2 , С. Д. Загородняя ${ }^{2}$ \\ ${ }^{1}$ Национальный фрармацевтический университет, Харьков \\ ${ }^{2}$ Институт микробиологии и вирусологии имени Д. К. Заболотного НАН Украины, Киев
}

\begin{abstract}
Резюме: изучена противовирусная активность таблеток Альтабор. Определено, что препарат обладает противогерпетической активностью как в лечебных, так и профилактических схемах применения.
\end{abstract}

Ключевые слова: альтабор, противогерпетическая активность, герпес, таблетки.

\section{STUDY OF ANTIHERPETHETICAL ACTIVITY OF TABLETS ALTABOR}

\author{
T. V. Krutskykh ${ }^{1}$, N. V. Nesterova ${ }^{2}$, S. D. Zahorodnya ${ }^{2}$ \\ ${ }^{1}$ National University of Pharmacy, Kharkiv \\ 2Institute of Microbiology and Virology of NAS of Ukraine, Kyiv
}

Summary: there studied was the antiviral activity of tablets Altabor. It was determined that the drug has antiherpetic activity as therapeutic and prophylactic use of schemes.

Key words: altabor, antiherpethetical activity, herpes, tablets. 